\title{
BIOLOGICAL ASPECTS AND INSECTICIDE ACTION OF PLANT SPECIES ON EGGS AND NYMPHS OF CITRUS BLACK FLY (Aleurocanthus woglumi Ashby - Aleyrodidae) AT LABORATORY LEVEL ${ }^{1}$
}

\author{
JULIANE DAMASCENO DE CARVALHO ${ }^{2}$, FELIPE LOPES NEVES ${ }^{3}$, \\ CLÁUDIA DURVAL DA SILVA4 ${ }^{4}$ MARIA APARECIDA LEÃO BITTENCOURT
}

ABSTRCT - Aleurocanthus woglumi Ashby (Hemiptera: Aleyrodidae) is an important pest of many plant species in particular citrus species. The aims of this study were: (1) to observe 'in vitro' biological aspects in three hosts and (2) to evaluate the bioactivity of plant species on immature A.woglum. Aqueous neem extract (Meliaceae), cassava wastewater, pepper sauce and gravy peduncle floral carnation guinea button and commercial neem were used in the experiment. Egg viability (\%), nymphal period duration, nymphal mortality (\%), puparium stage duration and pupae viability (\%) were evaluated in 50 egg positions, with minimum of five eggs in "Pera" orange, mango and malay apple leaves obtained in the field. The insecticide effect (translaminar action and direct spray) at different concentrations on immature $A$.woglumi was evaluated. The first bioassay conducted to evaluate the bioactivity of species by translaminar action, each sample unit corresponded to three leaves, with minimum of 20 eggs and $201^{\text {st }}$ instar nymphs, the variables were unviable eggs and nymph mortality (\%); the experiment had a completely randomized design with four replications. In the second bioassay, fully infected branches were sprayed on upper and lower face of leaves with all treatments. Leaves with at least 40 eggs and $401^{\text {st }}$ instar nymphs were marked, and mortality (\%) and emergence (\%) of adults were evaluated for seven days; each sample unit was represented by 40 eggs and $401^{\text {st }}$ instar nymphs and the experiment had a completely randomized design with four replications. The average duration of the nymphal period ranged from 7.76 to 24.18 days in "Pera" orange, and from 8.86 to 25.20 days in mango. There was no significant difference between the viability of eggs and nymphs in "Pera" orange and mango or pupae viability between "Pera" orange and malay apple. Treatment efficiency was evaluated using the Abbott's formula $[\mathrm{E}(\%)=\mathrm{T}-\mathrm{I} / \mathrm{T} \times 100]$, where $\mathrm{E}(\%)=$ efficiency percentage, $\mathrm{T}=$ number of live insects in the control treatment and $\mathrm{I}=$ number of live insects in treatment with insecticide. Therefore, in the first bioassay conducted to evaluate the bioactivity of species by translaminar action, all treatments showed efficiency greater than $50 \%$. In the second bioassay by direct spraying to cassava wastewater $(100 \%$ and $50 \%)$ and commercial neem oil (1\%), treatment had nymphal mortality efficiency greater than $80 \%$.

Index Terms: Azadirachta indica. Botanical insecticide. Manipueira.

\section{ASPECTOS BIOLÓGICOS E AÇÃO INSETICIDA DE ESPÉCIES VEGETAIS SOBRE IMATUROS DA MOSCA-NEGRA-DOS-CITROS (Aleurocanthus woglumi Ashby - HEMIPTERA: ALEYRODIDAE) EM LABORATORIO}

RESUMO - Aleurocanthus woglumi Ashby (Hemiptera: Aleyrodidae) é uma importante praga para diversas espécies botânicas, em especial as espécies cítricas. Os objetivos deste estudo foram: (1) observar in vitro aspectos biológicos em três hospedeiros (laranjeira-pera, mangueira, jambeiro-vermelho) e (2) avaliar a bioatividade de espécies vegetais sobre imaturos de A.woglum. Foram utilizados no experimento extrato aquoso de nim (Meliaceae), manipueira, calda de pimentas, calda do pedúnculo do botão floral do craveiro da índia e o óleo de nim comercial. Foi avaliada a viabilidade de ovos (\%), duração do período ninfal, mortalidade de ninfas (\%), duração da fase de pupário e viabilidade dos pupários (\%) em 50 posturas, com mínimo de cinco ovos, em folhas de laranjeira-pera, mangueira e jambeiro-vermelho obtidas em campo. Foi avaliado o efeito inseticida (ação translaminar e pulverização direta) em diferentes concentrações sobre imaturos de A.woglumi. No primeiro bioensaio, realizado para avaliar a bioatividade das espécies pela ação translaminar, cada unidade amostral correspondeu a três folhas, com mínimo de 20 ovos e 20 ninfas de $1^{\circ}$ ínstar, as variáveis avaliadas foram inviabilidade de ovos e mortalidade de ninfas (\%); o experimento foi em delineamento inteiramente casualizado, em quatro repetições. No segundo bioensaio, ramos infestados foram pulverizados totalmente, nas faces inferior e superior das folhas, com todos oss tratamentos. Folhas com, no mínimo, 40 ovos e 40 ninfas de $1^{\circ}$ instar foram marcadas, e durante sete dias foram avaliada a mortalidade (\%) e a emergência (\%) de adultos; cada unidade amostral foi representada por 40 ovos e 40 ninfas de $1^{\circ}$ instar, e o experimento foi em delineamento inteiramente casualizado, em quatro repetições. A duração média do período ninfal variou de 7,76 a 24,18 dias em laranjeira-pera, e de 8,86 a 25,20 dias em mangueira. Não foi observada diferença significativa entre a viabilidade de ovos e ninfas em laranjeira-pera e mangueira nem a viabilidade de pupários entre laranjeira-pera e jambeiro-vermelho. A eficiência dos tratamentos foi avaliada pela fórmula de Abbott $[\mathrm{E}(\%)=\mathrm{T}-\mathrm{I} / \mathrm{T} \times 100]$, onde $\mathrm{E}(\%)=$ porcentagem de eficiência, $\mathrm{T}$ = número de insetos vivos na testemunha $\mathrm{e}$ $\mathrm{I}=$ número de insetos vivos no tratamento com inseticida. Sendo assim, no primeiro bioensaio realizado para avaliar a bioatividade das espécies pela ação translaminar todos os tratamentos apresentaram eficiência maior que 50\%. No segundo bioensaio através da pulverização direta a manipueira (100\% e 50\%) e o óleo de nim comercial (1\%) apresentaram eficiência superior. Termos para indexação: Azadirachta indica, inseticida botânico, manipueira.

(Paper 063-16). Received April 28, 2016. Accepted October 25, 2016

${ }^{2}$ Agronomist. Graduate Program in Plant Production, State University of Santa Cruz (UESC). Email: julianedamasceno@agronoma.eng.br. Part of the Master Dissertation. Corresponding Author.

${ }^{3}$ Agronomist. Research Institute of Espírito Santo, Technical Assistance and Rural Extension (INCAPER) Email: felipe.neves@incaper.es.gov.br ${ }^{4}$ Agronomist. State University of Santa Cruz (UESC). Email: claudinhaduvale@gmail.com

${ }^{5}$ Agronomist. Department of Agrarian and Environmental Sciences, State University of Santa Cruz (UESC), 1. E-mail: malbitte@uesc.br 


\section{INTRODUCTION}

The citrus industry is a highly organized and competitive sector and has great representativity in the Brazilian agribusiness. Accounting for $60 \%$ of the orange juice world production, Brazil is the main exporter, and up to July 2016, about 254,239 tons were exported (CITRUSBR, 2016; BRASIL, 2016).

In the year 2014, the State of Bahia produced about $1,026,167$ tons of orange $(62,303 \mathrm{ha}), 67,559$ tons of lemon (3,405 ha) and 10,288 tons of tangerine (712 ha), having the "Recôncavo Baiano" as the main producing region (IBGE, 2016). Citrus plants are subject to the attack of several pests in their different stages of formation and development: sowing, nursery and orchard (EMBRAPA, 2016). One of the major pests affecting citrus production is the citrus black fly, Aleurocanthus woglumi Ashby (Hemiptera: Aleyrodidae), which is located on the underside of leaves. They cause direct damages by the continuous sap sucking and consequent decline in the vigor of plants, as well as indirect damages by favoring the appearance of sooty mold on leaves, branches and fruits, affecting respiration, photosynthesis and the quality of fruits for fresh commercialization, resulting in increased costs due to intensive washing during processing in the packing house.

This pest originated in Asia and is widespread in Africa, North, Central and South America, the Caribbean and Oceania (EPPO, 2008). The first occurrence in Brazil was in 2001, in Belém, state of Pará, and is currently disseminated in several states of the country, including Bahia (SILVA et al., 2010). Aleurocanthus woglumi is a pest of agricultural importance because it is polyphagous, with a record of more than 300 botanical species as hosts, including cultivated, wild and ornamental species (BARBOSA, 2007, MAIA, 2008, PENA et al. Sá et al., 2008; SILVA, 2010; SILVA et al., 2011).

Females lay their eggs in the form of a spiral on the abaxial face of leaves, which is a mechanism used in their protection against natural enemies and the action of abiotic factors. Several studies have shown that the number of eggs deposited in the form of a spiral is from 10 to 70.3 eggs (LEMOS et al., 2006; FARIAS et al., 2011; RAGA et al., 2012; MORAES et al., 2014), and the average number of eggs was 1.23 positions / leaf on "Pera" orange (Citrus sinensis L.) and 0.25 positions / leaf on tangerine (Citrus reticulata L.) (Rutaceae) in the state of São Paulo (IMPERATO et al., 2014).

Depending on the climate, the hatching of $1^{\text {st }}$ instar nymphs occurs between 4 and 12 days, and these nymphs are oval and elongated in shape, are hyaline and have short legs and antennae being the only nymph stage that is mobile, and after 7 to 16 days, they fix the mouth device on the leaf for the beginning of feeding. In laboratory conditions, $2^{\text {nd }}$ instar nymphs showed a duration of 6.94 and 7.36 days, and under field conditions, this period varied from 8 to 11 days, and for $3^{\text {rd }}$ instar nymphs, this period ranged from 6.36 to 9.96 days and the mean period of the puparium stage ( $4^{\text {th }}$ instar nymphs) was 33.58 days (Oliveira et al., 2001, CUNHA et al., 2003; RONCHI-TELES et al., 2009; LOPES et al. al., 2013).

The development of $A$. woglumi is favored by temperatures between $28^{\circ} \mathrm{C}$ and $32^{\circ} \mathrm{C}$, and relative air humidity between $70 \%$ and $80 \%$, not surviving at temperatures around $40^{\circ} \mathrm{C}$ and altitudes above 1,000 meters (EPPO, 2008).

There are currently only four insecticides registered in the Ministry of Agriculture, Livestock and Supply (MAPA), which are commonly recommended for the control of $A$. woglumi in citrus, three of which having neonicotinoid as active ingredient and the other one is based on pyrethroid and antranilamide (AGROFIT, 2016). The use of plant extracts as insecticides alternative to synthetic chemicals is a form of control that minimizes several problems inherent to the use of synthetic chemicals, which can be more economical and easier to handle, being a good option for small producers. The aim of this study was to observe at laboratory level the following biological aspects: egg viability, nymphal period duration, nymph mortality, puparium phase duration and puparia viability in three hosts and to evaluate the bioactivity of plant species on $A$. woglumi eggs and nymphs.

\section{MATERIAL AND METHODS}

\section{Biological aspects of $A$. woglumi in three hosts}

"Pera" orange, mango and malay apple leaves, collected on the campus of the State University of Santa Cruz (UESC) (14 47'41" S and 39 10'04" $\mathrm{W} ; 31 \mathrm{~m}$ a.s.1.), containing insect eggs were kept in climatic chamber (BOD) at $25 \pm 1^{\circ} \mathrm{C}$ and 12 -hour photoperiod. A total of 50 egg positions of each host were observed, with at least five eggs, and the following biological parameters were evaluated: egg viability (\%), duration of nymphal period 1 , nymph mortality (\%), puparium phase duration and puparia viability (\%). Results were submitted to analysis of variance (ANOVA) and the means were compared by the Tukey test at $5 \%$ of probability. 


\section{Bioassays with botanical insecticides on A. woglumi}

The translaminar action and the direct spray of different treatments on eggs and $1^{\text {st }}$ instar nymphs were evaluated. Treatments used were: aqueous extract of neem leaves (10\% and 20\%), and gravy peduncle floral carnation guinea button (10\% and $20 \%$ ), pepper sauce $(10 \%$ and $20 \%$ ), cassava wastewater (50\% and $100 \%)$ and commercial neem oil (1\%, and 2\%).

Aqueous neem extract was obtained by drying leaves in an oven at $50^{\circ} \mathrm{C}$ for 48 hours. Then, samples were ground and the powder was placed in distilled water for 24 hours for the extraction of compounds.

The preparation of the extract to obtain the pepper sauce was carried out from the maceration of $200 \mathrm{~g}$ of garlic; $50 \mathrm{~g}$ of black pepper; $50 \mathrm{~g}$ chili pepper; $50 \mathrm{~g}$ of cumarí pepper and $2 \mathrm{~L}$ of sugarcane brandy. Peppers sauce was obtained with the mixture of $50 \mathrm{~mL}$ of pepper extract, $20 \mathrm{~g}$ of brown sugar, 10 L of water and $35 \mathrm{~mL}$ of vinegar.

The gravy peduncle floral carnation guinea button extract was prepared by immersing $200 \mathrm{~g}$ of gravy peduncle floral carnation guinea button in $2 \mathrm{~L}$ of sugarcane brandy, and to obtain the gravy peduncle floral carnation guinea button, $50 \mathrm{~mL}$ of this extract were mixed with $20 \mathrm{~g}$ of brown sugar, $10 \mathrm{~L}$ of water and $35 \mathrm{~mL}$ of vinegar.

After preparation, sauces were stored in amber glass bottle under refrigeration until their use. Changes in the physical appearance or presence of fungi detectable at the time of application were observed (NEVES et al., 2005; SANTOS et al, 2009).

In order to evaluate the translaminar action, leaves infested with eggs and nymphs collected in the field were detached from plants, and by means of a hand spray, $50 \mathrm{~mL}$ of each treatment was applied on the adaxial part of leaves, that is, on the opposite face of the surface containing eggs and nymphs. The petioles of treated leaves were wrapped with moistened cotton to avoid dryness, and each was placed in a disposable Petri dish lined with moistened filter paper and covered with plastic film and conditioned in a climatic chamber (BOD) at $25 \pm 1^{\circ} \mathrm{C}$ and 12-hour photoperiod. Each sample unit corresponded to three leaves, with a minimum of 20 eggs and $201^{\text {st }}$ instar nymphs. Treatments were evaluated every 24 hours for up to seven days after application. The experimental design was completely randomized, with 11 treatments and four replicates. In another bioassay, citrus branches collected in the field were placed in voile cages, and new branches without egg position were placed inside the cages for reinfestation. The re-infested branches were labeled and sprayed with $50 \mathrm{~mL}$ of the different treatments. Each sample unit corresponded to three leaves, with a minimum of 40 eggs and $401^{\text {st }}$ instar nymphs, and after seven days, egg infeasibility and nymph mortality were evaluated. The design was repeated with 11 treatments and four replicates.

\section{Analysis of obtained data}

Data were submitted to statistical analysis (ANOVA) and the means were compared by the Tukey test at 5\% probability when significant. The efficiency of treatments (corrected mortality) was evaluated using the Abbott formula $[\mathrm{E}(\%)=\mathrm{TI} /$ $\mathrm{T} \times 100]$, where $\mathrm{E}(\%)=$ efficiency percentage, $\mathrm{T}=$ number of live insects in control treatment and I = number of live insects in insecticide treatment. The procedure to evaluate treatments under citrus black fly was performed seven days after application.

\section{RESULTS AND DISCUSSION}

\section{Biological aspects in three $A$. woglumi hosts under laboratory conditions}

Regarding egg viability, no significant difference was observed between "Pera" orange and mango. The average egg viability was $82.39 \%$, in "Pera" orange and $79.79 \%$ in mango, and in malay apple leaves, the viability was lower, with mean value of $66.15 \%$.

Also, no significant difference was observed in relation to nymph viability between "Pera" orange and mango hosts. The mean viability was $68.92 \%$ in "Pera" orange and $60.67 \%$ in mango, while the average viability was $50.28 \%$ in malay apple leaves (Table 1). No significant difference was observed between "Pera" orange and malay apple hosts regarding puparia viability. In "Pera" orange, the average viability was $70.02 \%$ and in malay apple, the average viability was $52.97 \%$; however, it was observed that in mango leaves, viability was lower, with mean value of $44.75 \%$, similar to that observed by Pena et al. (2009).

In relation to the nymphal period in "Pera" orange, $1^{\text {st }}$ instar of nymphs lasted on average 7.76 days, statistically differing from mango (8.86 days) and malay apple ( 9.42 days) (Table 1$)$. No significant difference was observed between the mean nymphal period duration of $2^{\text {nd }}$ instar, ranging from 7.78 days in orange, 7.86 days in mango and 10.96 days in malay apple. For $3^{\text {rd }}$ instar nymphs, the average 
duration was 7.86 days in orange and 8.10 days in mango, with no statistical difference, and in malay apple, it was 10.50 days, corroborating data found in other studies (RONCHI -TELLES et al., 2009; LOPES et al., 2013).

The puparium phase duration was 24.18 days on average in orange and 25.20 days in mango, with no significant difference, and in malay apple, this phase was longer, with mean duration of 26.66 days (Table 1). The puparium phase period was the longest, as found in other studies (CUNHA, 2003).

\section{Toxic effect of botanical extracts on immature $A$. woglumi by the translaminar method.}

In relation to egg viability, only commercial neem oil at the two concentrations analyzed (1\% and $2 \%$ ) presented efficiency above $50 \%$. At $1 \%$ concentration, the mean egg infeasibility was $61 \%$, and at $2 \%$ concentration, the mean value was $60 \%$ (Figure 1). The aqueous extract of neem leaves at $10 \%$ concentration did not differ statistically from cassava wastewater at both concentrations, with mean of $53.25 \%$ of nonviable eggs, and the aqueous extract from neem leaves (20\%) turned about 50.50\% of eggs unfeasible (Figure 1). Egg infeasibility was higher under the action of neem treatments, probably due to the presence of the azadirachtin substance, which has insecticidal power, as has been observed in other studies (MORDUE; NISBET, 2000).

Gravy peduncle floral carnation guinea button $(10 \%)$, cassava wastewater $(50 \%$ and $100 \%)$ and pepper sauce $(10 \%$ and $20 \%)$ treatments made infeasible about $45 \%$ of eggs (Figure 1). Gravy peduncle floral carnation guinea button at $20 \%$ concentration caused the unfeasibility of $32.50 \%$ of eggs, and in the control, only $16 \%$ of eggs were not feasible (Figure 1).

The low egg unfeasibility on citrus black fly eggs may be indicative that the bioactive compounds present in treatments used found a probable physical resistance of the chorion to the action of extracts, as also observed in other studies (GONÇALVES, 2010; PENA, 2012).

In the translaminar action on $1^{\text {st }}$ instar nymphs, all treatments determined mortality higher than $50.00 \%$. Cassava wastewater $(50 \%$ concentration) caused average mortality of $84.25 \%$, and at $100 \%$ concentration, the average mortality was $78.50 \%$ (Figure 2), probably due to the action of cyanogenic compounds (PONTE, 1999). Commercial neem oil at $2.0 \%$ concentration had toxic effect of $76.25 \%$, and at $1.0 \%$ concentration, the nymph mortality was $68.50 \%$ (Figure 2 ). The aqueous extract of neem leaves at concentration of $20 \%$ caused an average mortality of $78.25 \%$, and at $10 \%$ concentration, the mean mortality was $72.75 \%$, showing no significant difference (Figure $2)$. Under the action of pepper sauce, mean mortality ranged from $53.75 \%(10 \%)$ to $61.00 \%(20 \%)$, and gravy peduncle floral carnation guinea button $(20 \%$ concentration) caused average mortality of $52.20 \%$ (Figure 2), and these treatments did not present statistical differences among themselves. Gravy peduncle floral carnation guinea button sauce at 10\% concentration caused average mortality of $32.50 \%$, not statistically differing from control treatment $(17.50 \%)$ (Figure 2).

Toxic effect of botanical extracts on immature $A$. woglumi by the direct spray method.

The unfeasibility of citrus black fly eggs was greater than $85 \%$ by the direct spray of commercial neem oil $(1 \%$ and $2 \%)$ and cassava wastewater treatments (100\%) (Figure 3). Pepper sauce (10\%) caused mean egg unfeasibility of $69.25 \%$, and at $20 \%$ concentration, egg unfeasibility was $78.00 \%$. Under the action of cassava wastewater (50\%), aqueous extract of neem leaves (20\%), and gravy peduncle floral carnation guinea button $(20 \%)$, egg unfeasibility was higher than $70 \%$, and under gravy peduncle floral carnation guinea button $(10 \%)$ and aqueous extracts of neem leaves (10\%), the mean egg unfeasibility was close to 50\% (Figure 3).

In direct spray on $1^{\text {st }}$ instar nymphs, treatments that caused mean mortality of $80 \%$ were, respectively, cassava wastewater $(50 \%$ and $100 \%$ concentration), with mean of $80.5 \%$ and $89 \%$, respectively (Figure 4 ), showing the efficacy of cassava wastewater on mite mortality (SANTOS et al., 2012) and commercial neem oil ( $1 \%$ concentration), with mean of $86 \%$, not statistically differing from cassava wastewater (Figure 4).

Commercial neem oil (2\%) caused mortality of $81.00 \%$, and due to the action of the aqueous extract of neem leaves (20\%), mortality was of $77 \%$, not statistically differing from each other (Figure 4). These results are similar to those obtained in another study with application of neem-based commercial products (SILVA et al., 2012).

Pepper sauce (10\% and $20 \%$ concentration), aqueous extract of neem leaves $(10 \%)$ and the gravy peduncle floral carnation guinea button $(20 \%)$ caused mean mortality above $65.00 \%$ of $1^{\text {st }}$ instar nymphs of citrus black fly, showing no significant differences. Gravy peduncle floral carnation guinea button at 
$10 \%$ concentration caused mortality of $36 \%$, and in the control treatment, mortality was 24\% (Figure 4).

Average efficiency of the different treatments on immature $A$. woglumi under translaminar effect.

It was observed that none of treatments under translaminar action presented ovicidal effect above $80 \%$ (Figure 5). Probably, the effect on nymphs has been greater because they are more susceptible and suck sap from leaves (GONÇALVES, 2010; PENA, 2012).

Under translaminar action, it was observed that the aqueous extracts of neem leaves $(10 \%$ and $20 \%)$, cassava wastewater $(50 \%$ and $100 \%)$ and commercial neem oil ( $1 \%$ and $2 \%$ ) have efficiency higher than $80 \%$, according to the Abboutt formula, and can be considered the best treatments for nymphal phase control of the citrus black fly (Figure 6).

Average efficiency of the different treatments on immature $A$. woglumi by the direct spray method

Only treatments aqueous extract from neem leaves $(10 \%$ and $20 \%)$, cassava wastewater $(50 \%$ and $100 \%)$ and commercial neem oil (1\% and $2 \%)$ presented efficiency above $80.00 \%$, being considered efficient in the control of citrus black fly in the egg (Figure 7) and $1^{\text {st }}$ instar phases (Figure 8), as was also observed by Gonçalves (2010).

In direct spraying, the efficiency of all treatments exceeded $70 \%$, being evident that the control of the citrus black fly can be carried out with products alternative to synthetic chemicals (Figure 8).

TABLE 1 - Biological aspects of citrus black fly in three host species under laboratory conditions.

\begin{tabular}{cccccccc}
\hline Host & $\mathrm{Vo}(\%)$ & $\mathrm{Vn}(\%)$ & $\mathrm{Vp}(\%)$ & Pn1(days) & Pn2(days) & Pn3(days) & Pp(days) \\
\hline Pera orange & $82,39 \mathrm{a}$ & $68,92 \mathrm{a}$ & $70,02 \mathrm{a}$ & $7,76 \mathrm{a}$ & $7,78 \mathrm{a}$ & $7,86 \mathrm{a}$ & $24,18 \mathrm{a}$ \\
\hline Mango & $79,79 \mathrm{a}$ & $60,67 \mathrm{a}$ & $44,75 \mathrm{a}$ & $8,86 \mathrm{a}$ & $7,86 \mathrm{a}$ & $8,10 \mathrm{a}$ & $25,20 \mathrm{a}$ \\
\hline Malay apple & $66,15 \mathrm{~b}$ & $50,28 \mathrm{~b}$ & $52,97 \mathrm{a}$ & $9,42 \mathrm{~b}$ & $10,96 \mathrm{~b}$ & $10,50 \mathrm{~b}$ & $26.66 \mathrm{a}$ \\
\hline
\end{tabular}

$* \mathrm{Vo} \%=$ Egg viability; $\mathrm{Vn} \%=$ Nymph feasibility; $\mathrm{Vp} \%=$ puparia viability; Pn1 (days) = Average duration of the $1^{\text {st }}$ instar nymph period; Pn2 (days) = Average duration of the $2^{\text {nd }}$ instar nymph period; Pn3 (days) = Average duration of the $3^{\text {rd }}$ instar nymph period; $\mathrm{Pp}($ days $)=$ Mean duration of the puparium period. Data compared in columns.

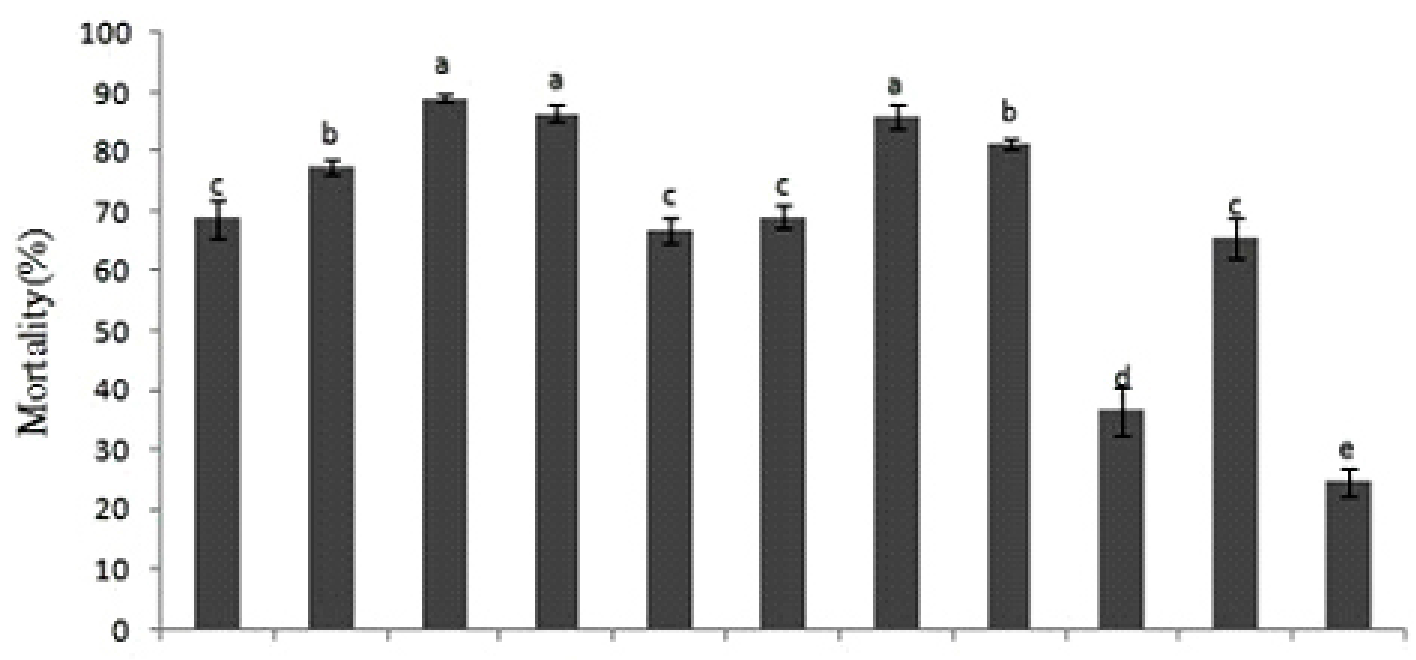

NE $10 \%$ NE20\% MANI MANI PC $10 \%$ PC20\% NO1\% NO2\% CC10\% CC20\% T $100 \% 50 \%$

FIGURE 1 - Unfeasibility (\%) of citrus black fly eggs by translaminar action of different treatments. 


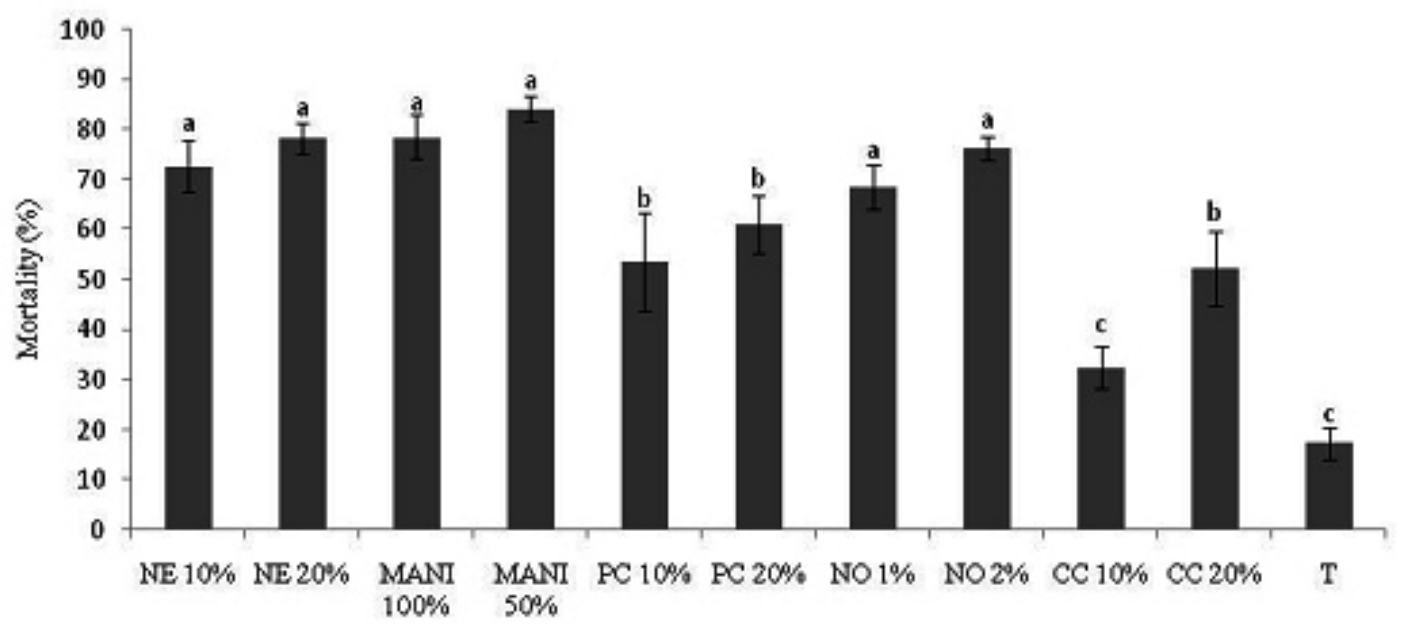

FIGURE 2 - Mortality (\%) of $1^{\text {st }}$ instar nymphs of citrus black fly by translaminar action of different treatments.

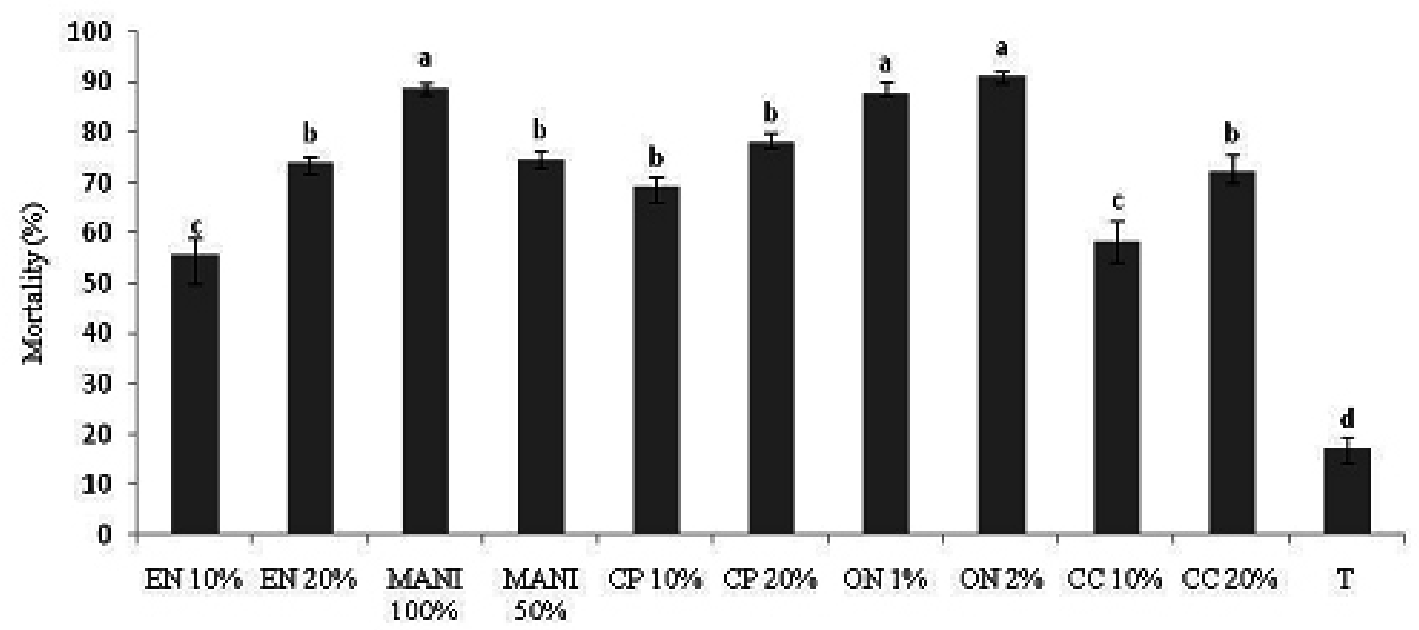

FIGURE 3 - Unfeasibility (\%) of citrus black fly eggs by direct spraying of different treatments.

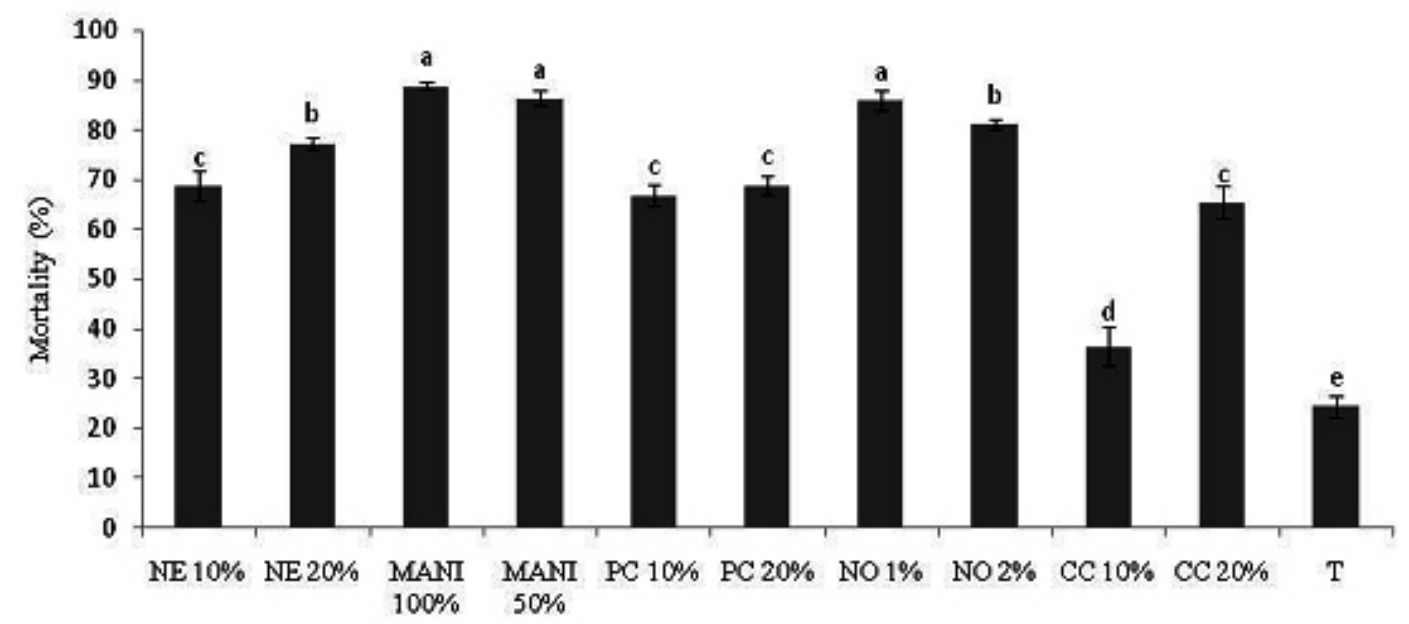

FIGURE 4 - Mortality (\%) of $1^{\text {st }}$ instar nymphs of citrus black fly under the effect of direct spraying of different treatments. 


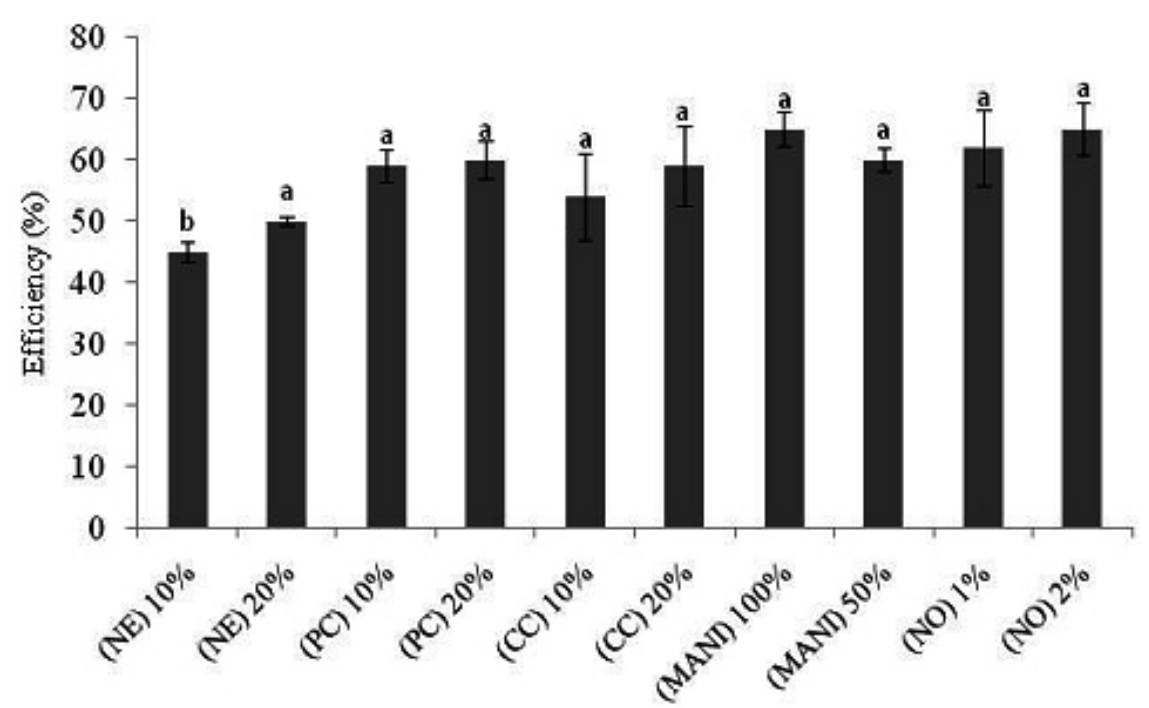

FIGURE 5 - Mean efficiency of the different treatments on $A$. woglumi eggs under the translaminar effect.

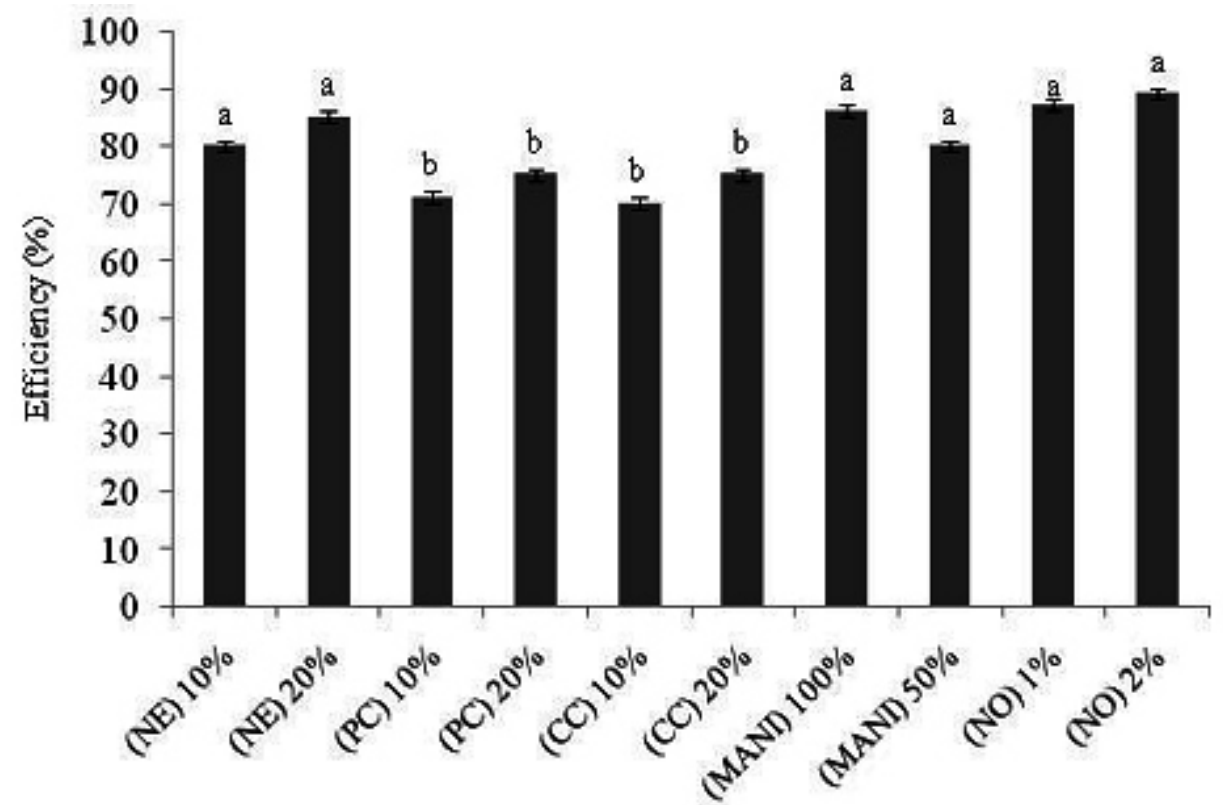

FIGURE 6- Average efficiency of the different treatments by the translaminar action on $1^{\text {st }}$ instar nymphs of $A$. woglumi. 


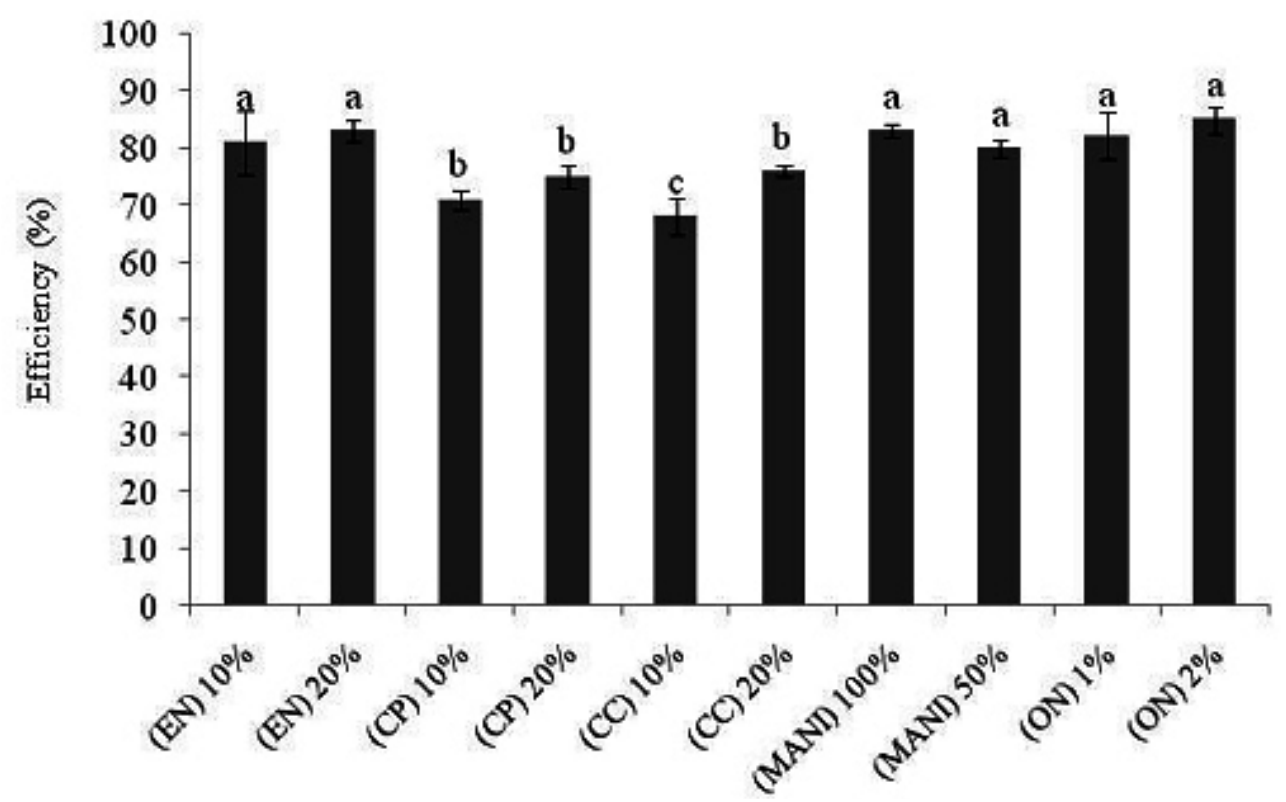

FIGURE 7 - Mean efficiency of the different treatments on $1^{\text {st }}$ instar eggs of $A$. woglumi by the direct spraying method.

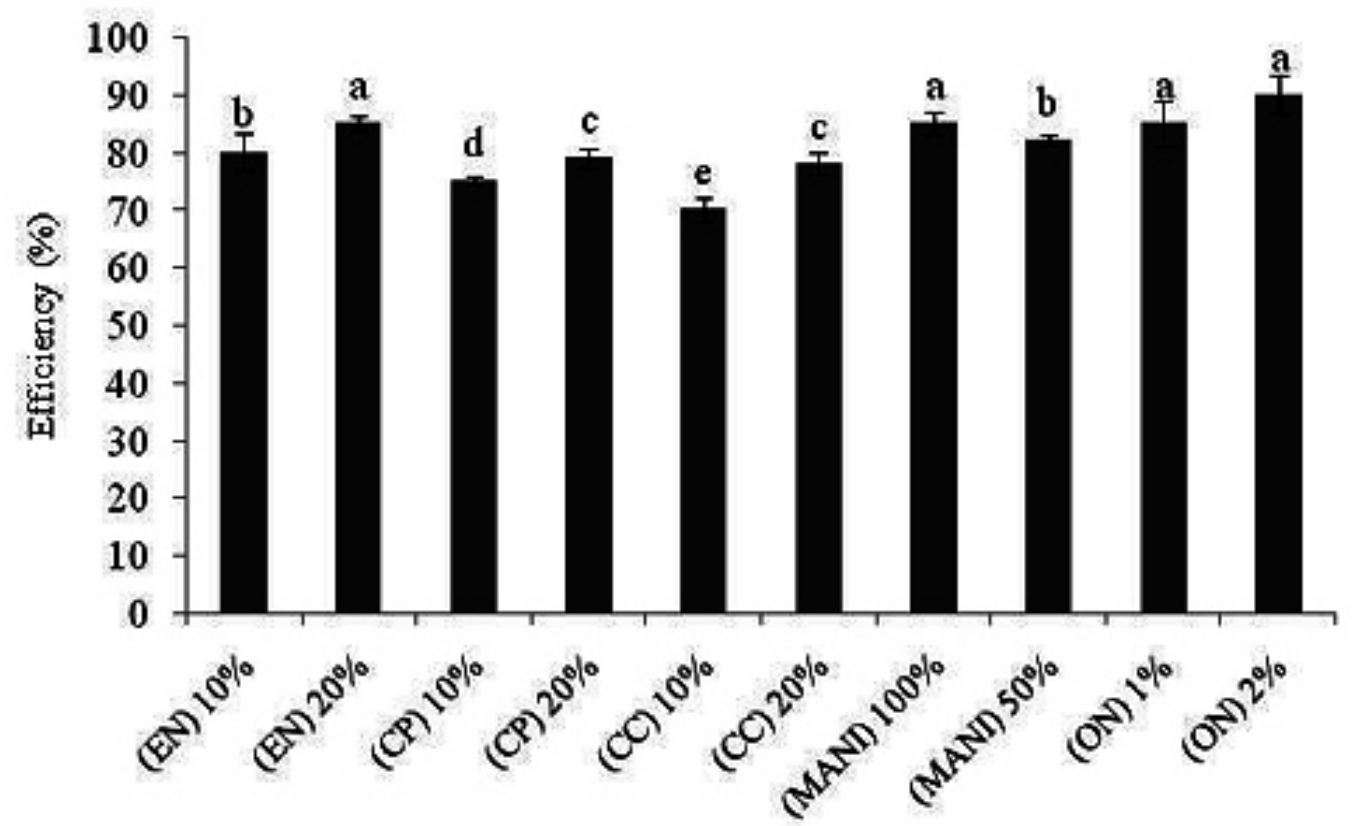

FIGURE 8 - Mean efficiency of different treatments directly sprayed on $1^{\text {st }}$ instar nymphs of $A$. woglumi. 


\section{CONCLUSIONS}

Azadirachta indica and cassava wastewater are efficient in the control of the citrus black fly.

The method of direct application of treatments is efficient in the control of eggs and $1^{\text {st }}$ instar nymphs of the citrus black fly.

\section{ACKNOWLEDGMENTS}

To the Foundation for Research Support of the State of Bahia (FAPESB) for granting the scholarship to the first author, to the State University of Santa Cruz (UESC) for the opportunity of Master's degree in Plant Production and to all those who somehow contributed to the accomplishment of this work.

\section{REFERENCES}

AGROFIT. Agrofit consulta aberta. 2016. Disponível em: < http://agrofit.agricultura.gov.br/ agrofit_cons/principal_agrofit_cons $>$. Acesso em: 31 ago. 2016.

BARBOSA, F. R. Pragas de risco da mangicultura no Brasil. In: SIMPÓSIO DE MANGA DO VALE DO SÃO FRANCISCO, 2., 2007, Petrolina. Resumos... p. 6-13.

BRASIL. Ministério da Agricultura, Pecuária e Abastecimento. Cultura dos citrus. Brasília, 2016. Disponível em: <http://www.agricultura.gov.br/ vegetal/culturas/citrus.pdf. $>$. Acesso em: 20 ago. 2016.

CITRUSBR. Mercado externo: estatística de exportação. Disponível em: $<$ http://www.citrusbr. $\mathrm{com} /$ mercadoexterno $/$ ?me $=01>$. Acesso em: 20 ago. 2016.

CUNHA, M.L.A. Distribuição, hospedeiros, densidade populacional, aspectos biológicos e controle químico da mosca-negra-dos-citros (Aleurocanthus woglumi Ashby) nas condições do Estado do Pará. 2003. 54 f. Dissertação (Mestrado em Agronomia) - Universidade Federal Rural da Amazônia, Manaus, 2003.

EMBRAPA. Citros. Brasília, 2016. Disponível em: $<$ https://www.embrapa.br/mandioca-e-fruticultura/ cultivos/citros $>$. Acesso em 20 ago. 2016.
EPPO - European Plant Protetion Organization. Quarabtine pest Aleurocanthus woglumi. Paris, 2008.

FARIAS, P.R.S.; MAIA,S.P.P.; SILVA,A.G.S.; MONTEIRO, B.S. Ocorrência de Aleurocanthus woglumi em área de reflorestamento com mogno africano na Amazônia Oriental. Revista Ciências Agrárias, Manaus, v.54, n.1, p.85-88. 2011.

GONÇALVES, M.L. Atividade ovicida e ninficida de diferentes extratos de meliáceas sobre a mosca-negra-dos-citros. 2010. 34f. Monografia. (Conclusão do curso de Bacharelado em Ciências Biológicas)- Universidade Federal do Amazonas, Manaus, 2010.

IBGE. Estados@. Rio de Janeiro, 2013. Disponível em: IBGE. Estados@. Rio de Janeiro, 2013. Disponível em: http://www.ibge.gov.br/estadosat/ temas.php?sigla=ba\&tema=lavourapermanete2013. Acesso em: 20 ago. 2016. Acesso em: 20 ago. 2016.

IMPERATO, R.; RAGA, A.; BARBOSA, J.C. Dinâmica populacional da mosca-negra-doscitros Aleurocanthus woglumi Ashby (Hemiptera: Aleyrodidae) em dois pomares cítricos de Artur Nogueira, região centro-leste do estado de São Paulo. In: CONGRESSO BRASILEIRO DE ENTOMOLOGIA, 25., 2014, Goiânia. Anais...

LEMOS, R.N.S.; SILVA, S.V.; ARAÚJO, J.R.G.; MOREIRA, A.A.; SOARES, A.T.M. Ocorrência de Aleurocanthus woglumi Ashby (Hemiptera: Aleyrodidae) no Maranhão. Neotropical Entomology, Curtitiba, v.35, n.4, p.558-559, 2006.

LOPES, G.S.; LEMOS, R.N.S.; ARAÚJO, J.R.G.; MARQUES, L.J.P.; VIERA, D.R. Preferência para oviposição e ciclo de vida de mosca-negra-doscitros Aleurocanthus woglumi Ashby em espécies frutíferas. Revista Brasileira de Fruticultura, Jaboticabal, v.35, n.3, p.738-745, 2013.

MAIA, P.S.P. Caracterização da distribuição espacial da mosca negra dos citros (Aleurocanthus woglumi Ashby, 1915) em pomar georreferenciado para determinar um plano de amostragem seqüencial. 2008. 77 f. Dissertação (Mestrado em Produção Vegetal) - Universidade Federal Rural da Amazônia, Manaus, 2008. 
MORAES, B.C.; SOUZA, E.B.S.; RIBEIRO, J.B.M.R.; FERREIRA, D.B.S.; MAIA, W.J.S.M. Impactos das mudanças climáticas na ecoclimatologia de Aleurocanthus woglumi ashby, 1903 (Hemiptera: Aleyrodidae) no estado do Pará. Revista Brasileira de Climatologia, Curitiba, v.29, n.1, p.77-84, 2014.

MORDUE, A.J.; NISBET, A.J. Azadirachtin from the neem tree Azadirachta indica: its action against insects. Anais da Sociedade Entomológica do Brasil, Curitiba, v.29, n.4, p.615-632, 2000.

NEVES, W.S.FREITAS, L.G.; DALLEMOLEGIARETTA, R.; FABRY, C.F.S.; COUTINHO, M.M.; DHINGRA, O.D .; FERRAZ, S.; DEMUNER, A.J. Atividade de extratos de alho (Allium sativum), mostarda (Brassica campestris) e pimenta malagueta (Capsicum frutenscens) sobre a eclosão de juvenis de Meloidogyne javanica. Nematologia Brasileira, São Paulo, v. 29, n. 2, p. 273-278, 2005.

OLIVEIRA, M.R.V.; SILVA, C.C.A.; NÁVIA, D. Mosca-negra-dos-citros Aleurocanthus woglumi: alerta quarentenário. Brasília: Ministério da Agricultura, Pecuária e Abastecimento, 2001.

PENA, M.R.; SILVA, N.M.; VENDRAMIM, J.D.; LOURENCAO, A.L.; HADDDAD, M.L. Biologia da mosca-negra-dos-citros, Aleurocanthus woglumi Ashby (Hemiptera: Aleyrodidae), em três plantas hospedeiras. Neotropical Entomology, Curitiba, v.38, n.2, p.254-261, 2009.

PENA, M.R. Bioatividade de extratos aquosos e orgânicos de diferentes plantas inseticidas sobre a mosca-negra-dos-citros, Aleurocanthus Woglumi Ashby 1915 (Hemiptera: Aleyrodidae). 2012. 188f. Tese (Doutorado em Agronomia Tropical) Universidade Federal do Amazonas, Manaus, 2012.

PONTE, J.J. Cartilha da manipueira: uso do composto como insumo agrícola. Fortaleza: Secretaria da Ciência e Tecnologia do Ceará, 1999. $53 p$.

RAGA, A BASILLI, J. F. M. ; SOARES, D. Z. Comportamento de oviposição da mosca-negrados-citros Aleurocanthus woglumi (Hemiptera: Aleyrodidae) em plantas cítricas. Idesia, Santiago, v.30, n.2, p.111-114, 2012.
RONCHI-TELES, B; PENA, M.R; SILVA, N.M. Observações sobre a ocorrência de mosca-negrados-citros, Aleurocanthus woglumi Ashby, 1915 (Hemiptera: Sternorrhyncha: Aleyrodidae) no Estado do Amazonas. Acta Amazônica, Manaus, v.39, n.1, p.240-244, 2009.

ROSSATO, V. Ocorrência de parasitóides de Aleurocanthus woglumi Ashby, 1903 (Hemiptera: Aleyrodidae) e seu parasitismo por Cales noacki Howard, 1907 (Hymenoptera: Aphelinidae) nos municípios de Belém, Capitão Poço e Irituia no Estado do Pará. 2007. 70 f. Dissertação (Mestrado em Produção Vegetal) - Universidade Federal Rural da Amazônia, Manaus, 2007.

SÁ, L.A.N. de; TAGLIARI, B.T.; OLIVEIRA, M.R.V.; ALMEIDA, G.R.; ROCHA, A.B.O. Mosca-negra-dos-citros Aleurocanthus woglumi Ashby (Hemiptera: Aleyrodidae) em culturas de citros e de mangueira no Estado de São Paulo e observações de sua biologia e controle. Brasília: Embrapa, 2008. 4p. (Comunicado Técnico, 46).

SANTOS, A.V.F. dos; BRITO, W.J.P.; FARIAS, P.R.S. Mosca-negra-dos-citros (Aleurocanthus woglumi), praga potencial para citricultura da Amazônia: determinação do nível de dano econômico. In: SEMINÁRIO ANUAL DE INICIAÇÃO CIENTÍfICA, 6., 2009, São José dos Campos. Anais... p. 1-5.

SANTOS, R.M.V.; NORONHA, A.C.S.; CORRÊA, F.M.; BITTENCOURT, M.A.L. Avaliação de defensivos naturais para o controle de Tetranychus abacae Baker \& Pritchard (Acari: Tetranychidae) em flores tropicais. Revista de Agricultura, São Paulo, v.87, n.1, p.59-65, 2012.

SILVA, A.D.; FARIAS, P.R.S.; BOICA JUNIOR, A.L.; SOUZA, B.H.S. Mosca-negra-dos-citros: características gerais, bioecologia e métodos de controle dessa importante praga quarentenária da citricultura brasileira. EntomoBrasilis, Seropédica, v.4, n.3, p.85-91, 2011.

SILVA, A.G. da. Dinâmica populacional de mosca-negra-dos-citros (Aleurocanthus woglumi Ashby, 1915) em pomares de citros em sistema agroflorestal e monocultura. 2010.79 f. Dissertação (Mestrado em Agronomia) - Faculdade de Ciências Agrárias e Veterinárias, Universidade Estadual 
Paulista, Jaboticabal, 2010

SILVA, J.C.; BATISTA, J. L. ; SILVA, J. G.; BRITO, C. H. Use of vegetable oils in the control of the citrus black fly, Aleurocanthus woglumi (Hemiptera: Aleyrodidae). Revista Colombiana de Entomología,Colômbia v. 38 , n. 2, p. 182-186 , 2012.

SILVA, S.X.B.; SOARES, A.C.F.; MAIA, W.J.M.S.; LOBO, C.G.B.; RODRIGUES, D.; FRÓIS, R.J. Mosca-negra-dos-citros (Aleurocanthus woglumi Ashy) na Bahia: detecção e medidas de controle. In. REUNIÃO REGIONAL DA SBPC NO RECÔNCAVO DA BAHIA, 2010, Cruz das Almas. Anais... Cruz das Almas: UFRB, 2010. 